\title{
Media as a Power in Man of the Moment by Alan Ayckbourn
}

\author{
Dr. Uğur Diler, PhD \\ Assistant Professor \\ Artvin Çoruh University \\ Turkey
}

\begin{abstract}
Alan Ayckbourn, briefly, presents nature of 'good' and 'evil', classical themes, in the play 'Man of the Moment'. The villain, Vic, is like the one who devoted himself to fame and to be a celebrity, and the instrument or institution here to lead the villain is media as a modern manipulator. Douglas, the other major character is the good one in the play without envy and jealousy. Jill, a TV reporter, stands as a manipulator representing the media. 'Man of the Moment' is a story of a forgotten hero, an evil man becoming a celebrity and a folk hero, and the media distorting reality by using its power to lead. What is original about the play is Ayckbourn's modern approach on examining 'good' and 'evil' morally with regard to media. This paper will seek to make a modest contribution to academic field, and particularly Foucault's thoughts and theories on power will be representatively applied to 'Man of the Moment' by Alan Ayckbourn.
\end{abstract}

Keywords: Ayckbourn, Foucault, media, power, manipulator, good, evil

\section{Introduction}

'Man of the Moment' is simply the story of good and evil. In essence, Douglas, a bank clerk, is good in spirit and Vic, the bank robber and a mega star now, is evil. It is like a story of love and hate, and as Ayckbourn, in an interview (1996), pointed out it is a play the audience needs to walk carefully the tightrope between comedy and tragedy (Murgatroyd 2009, p.20).It seems that Ayckbourn's aim is to make people think about morality by giving and implying these contrasts, particularly considering these two characters among others. While dealing morally with good and evil, the play describes media as a leading power on people. To write about the plot briefly, Douglas, a bank clerk, prevents a bank robbery and saves a hostage, Nerys, whom he loves platonically, but she is hurt permanently in the meanwhile of the incident by the bank robber, Vic. Eventually, Douglas marries Nerys, and Vic goes to prison. After Vic is released, he becomes a celebrity, rich and a folk hero by support of the media. Seventeen years later, Jill, an ambitious TV presenter, wants to confront Douglas and Vic in Vic's villa in Spain.

Name of the play is contradictory if one considers Vic and Douglas. There is irony in the title of the play when one thinks about both characters' social status and qualities. On the one hand, it is clear that Vic is 'man of the moment' in the condition what he lives and Douglas is not. On the other hand, Douglas is really 'man of the moment', but man of that moment when he was a hero for a short time after preventing robbery in a way. After the media as a dominant power determined the one who would be a celebrity, Douglas would be the man of the short moment, and Vic would be the man of the longer moment (like choosing good or bad side, but of course it is arguable what is good or bad in what sense and according to whom - whose benefit?). Murgatroyd, in his notes on 'Man of the Moment', states the situation considering the irony of the play's name: "While the audience is aware of the true nature of Vic, the play's ultimate irony is at the climax Vic is portrayed as the ultimate good guy as a result of Jill Rillington's amoral decision to rewrite history to essentially benefit herself - the man of the moment having passed from Douglas to Vic to Jill” (2009, p.32).

Like 'Woman in Mind', 'Man of the Moment', too, is Ayckbourn's look into individuals and indirectly society in modern world. As Murgatroyd (2009, p.5) states the plays present Ayckbourn's perception of the state of the nation at that time. They deal with Alan's disenchanted view of the contemporary world. Eventually, people have forgotten or have not concerned the details of the bad event (robbery, incident of Nerys) and the villain. The villain has become a hero; almost no one remembers the innocent people; the fake hero has been wealthy; people do not wait for the story of 'good' to rise, they wait and demand for the story of 'bad'. As Ayckbourn points out intending the public interest, 'Based on the unoriginal but eternally true observation that good news is no news and bad news is good news'. 
The audience watch the characters and events on TV like they are not real and one of them, like all are fictitious; the robbery, hurt people. It is blurred whether public wants such incidents and the media offers or vice versa, but the media leads and offers it for the sake of its own benefit. Therefore, Vic moves on to present high rated programs on TV, even Douglas is a fan of him. When he first meets Vic after seventeen years in Vic's villa, Douglas tries to say that he is a fan of Vic, and he is interrupted by Vic; "Hallo. Great to meet you. I'm a real fan -“. After Vic and Jill's conversation, Douglas completes his words by answering Vic's question if he has children, which will be repeated several times by Vic later; "No, no. But I watch your program. I watch Ask Vic every Tuesday" (Act I, p.20). It is highly ironic in terms of Douglas's unusual goodness and people's approach on good and evil from point of view of the media.

\section{Man of the Moment: Characters and the Media}

It seems that media is in the center as a power leading Vic, the central character, and others. Vic, in a sense, has devoted himself to media - to reputation actually, and become addicted to cameras. It can be clearly understood from what he says when he first enter the stage. "Well, where are the cameras then? Where're the cameras? I thought this place would be a mass of people... I make my special entrance. Get dressed up specially..." (Act I, p.19). He is a dominant character in order to continue to be popular and satisfy himself. Vic talks in terms of morality, using codes of morality for his own sake, as if he is right, partly, about what he did in the bank. However, he talks in a way what the media wishes, in false values. His utterances after Jill's exploitation by using the three people's irony are a good example of Vic and the media's cooperation using their power for mutual benefit: "If you think I didn't spend nine years of my life thinking about that girl, then you don't know me... I paid... I paid the full penalty as prescribed by the law for what I did." (Act I, p.31) If we consider that the interview will be aired to public, he, in a sense, repents that he does not think anymore about what he did in the bank incident, however he says he did in jail. Most probably, a number of the audience will believe what he said, and thus he will be falsifying the truth. This is an example of how media distorts truth. Ayckbourn (1995, Introduction to Alan Ayckbourn: Plays 1) depicts why the media manipulates reality: Whereas [the camera] doesn't tell flat lies, the camera often tells less than the whole truth. And to make it work for us we master techniques and tricks, all those skills which come naturally to the manipulators, the dissemblers and the con men but which are often beyond the capability of the earnest, the decent and the sincerely honestMurgatroyd (2009, p.19).

Media's power to manipulate reality reveals itself with tragicomic scenes in the play. For instance, the scene (Act I) Jill wants to film Vic and Douglas's confrontation some time after Vic and Douglas saw each other and had a conversation is, as Michael Billington states, the artificiality of television Murgatroyd (2009, p.30), and an example of manipulation.

Douglas Beechey is the other major character of the play standing opposite of Vic. Good and evil is particularly questioned via these two characters. Douglas is normally the hero and good one after causing Vic, the bank robber, to be arrested. However, Douglas is like a 'hero for 15 minutes' what Andy Warhol stated in terms of popular culture. After going out of prison, Vic becomes a celebrity and in a sense a hero with the very help of media. He has become a famous person, like a hero, though he is actually infamous. People know him, follow him on TV, his books, and even ask for help. The other one, Douglas, has been forgotten as a real hero. Media makes Vic a star and rich, and it does not do anything subsequently for Douglas, even to remind him depending on the incident. Media uses Vic as a central character to manipulate events, and of course reality presented to public, for the sake of its benefit. In addition, Vic, devoted himself into the way that media designates, is the most dominant character of all. The nature of good can be argued considering Vic's situation in reality and from point of view of society following him on TV.

Vic has an ability to control everyone around him, even Jill, the TV presenter. He has influenced her, and while doing the program, she ignores his caprices - late coming, talking in a way what he wants without considering Jill's directions. For instance, when Jill tries to explain what they will do for the program, Their Paths Crossed, Vic suddenly rises and goes off. He seems as if he listens to Jill, and Jill goes on to explain by shouting after him (Act I, p.23). Vic shows himself not only to people around him but to public with the help of the media. Accordingly, Foucault's (1982, p.786) expressions on exerting power over others that characterizing the power we are analyzing is that it brings into play relations between individuals (or between groups) are right if thought in parallel with those relations in the play. 
The apparent character leading the events in a way that she wants and does not allow anything that she does not want is Jill, working for the media. It seems in the play that Jill, the representative of media, is behind the events as an ambitious and insistent character. She organizes everything in what she wants; she prevents something which does not concern her benefits. Accordingly, she is a representative of media and media, as a power, manages the events - and characters - by using Jill. Especially Vic and Douglas are tools for Jill, and because media allows her to do, Jill, too, is a tool of media. It is obvious that Jill has a purpose to exploit the irony of Douglas's '15 minutes fame' after the bank incident as being a real hero, and Vic's becoming a celebrity and rich as a villain.

In terms of questioning identity and self considering the power of the media, the most highlighted characters are Jill, as an instrument of the media, and Vic, a, fake, hero, as in relation with Jill. It can be an argument to Foucault's claim of power's being a relation between individuals or institutions, not a thing centrally in one's hand. Foucault developed - in both Discipline and Punish and The History of Sexuality, volume 1, An Introduction (1976) - an influential account of the interconnections among power, knowledge and the subject(Leitch, 2001, p.1618).

When it is thought and heard about the term 'media', the mass media generally comes to mind. However Marshall McLuhan's definition of media has a widened perspective on how media affect people's life, especially in a modern society: "You have to understand that my definition of media is broad: it includes any technology whatever that creates extensions of the human body and senses, from clothing to the computer" (McLuhan, 1995, p.239).

It is understood from this definition that for people from what to wear to what to use as a device are a communication medium surrounding social life. To emphasize the fact that media have a tremendous effect on social life, McLuhan expresses the effect clear and concise: "Today, in the electronic age of instantaneous communication, I believe that our survival, and at the very least our comfort and happiness, is predicated on understanding the nature of our new environment because unlike previous environmental changes, the electric media constitute a total and near instantaneous transformation of culture, values and attitudes" (McLuhan, 1995, pp.238-239).

Vic asks questions to Douglas about his sexual life with his wife, Nerys.Moreover, he insists on asking about the same topic. He repeats the same question that if Douglas has children. Douglas confesses Trudy, Vic's wife, that he and Nerys have a non-sexual life. On the other hand, Vic seems highly sexy as a mega star of TV. Gauntlet emphasizes that sex is at the heart of identity today. It is clearly suggested by the media, the discourses of magazines, self-help books, that, for happiness, you should: understand your own sexuality; have sex often; seek help for sexual problems; have a satisfactory sexual partner - or get a new one Gauntlett goes on to express that talk shows, dramas, magazines and other media all relay these points (2002, p.122-123). If you see the cover of the program for the world premier showing Vic's fitted body in the pool, you will have an idea of how a popular culture star is presented, or 'shaped', by the media (Murgatroyd 2009, p.20). As Storey points out, the increasing number of celebrity surveillance magazines, such as Reveal, Closer, Heat and New, work in a similar way. Celebrities are monitored and scrutinized, especially in terms of body size and sexual and social behaviour, for our supposedly anonymous pleasure and entertainment. (2008, p.133). Vic is already described in such way physically. There is not a clear evidence for Vic if he was in a magazine, but in the play he is described and presented as in such celebrity magazines that Storey expressed. It is expected the audience's admiration of those celebrities, and the audience already admires, as part of a planned approach of power (a medium or all media). Therefore, Vic has fans of his TV shows (and him accordingly). As he is a fitted, good looking, helpful person as a mega-star of the media, he has most probably desired by many women who follows him. Even Sharon, the nanny, started working there because of her love to Vic. Eventually she confesses her purpose of working in the villa; "And he used to tell us on the telly if we had problems how to deal with them and not to worry and then when I got this job working for him I just thought (...)" (Act II, p.76). She confesses Trudy, Vic's wife, that she used to watch Vic on TV and fell in love (Act II, p.75).

In the play while discussing the incident, the robbery attempt, Vic tries to show himself as not really guilty, and implies that he did not really intend to harm that woman he hurt (permanently) (Act I, pp.32-34). He speaks and in a way confesses in terms of ethics, but in fact it is not a religion based ethics. He knows his speech will be broadcasted on TV and (im) morally he tries to seem innocent, even partly. 
It is obvious, as Foucault explained about the source of ethics in terms of 'technologies of the self', that Vic's concern is not religious while trying to make him 'less guilty' in some parts of the bank incident. In other words, his sayings are a reflection of a kind of 'inner ethics'(Gauntlett, 2002, pp.126-127). This is a false moral approach under the influence of the media's manipulation; he has a power by using the media, and media has a power to show/present it to public, and eventually Vic has fans. Thus, Foucault's "power is not an asset which a person can have; rather, power is something exercised within interactions. Power flows through relationships or networks of relationships" is a proper definition considering the use of power in a modern society (Gauntlett, 2002, pp.117). Such use of power is supported with the definition of power by Foucault that power is not a thing but a relation. Therefore, Gutting states it is, that no single center of power, a challenge to previous, traditional power approaches of Marx and others. (2005, p.87).

\section{Foucault and Power, and the Media in 'Man of the Moment'}

Foucault (1979, p.209) states that modern society is under the regime of prison (in the school, in the hospital, in the army, in social interactions, etc.) that there is a control, surveillance, and a discipline. If one thinks about how that 'discipline' is by considering the effect of media on people, one will understand this control mechanism from an example that is about Foucault's expressions on power of the media he experiences in his country (France).

"What bothers me is the quality of French television. It's true! It is one of the best in the world unfortunately!... What bothers and irritates me horribly in France, is that you are obliged to look at the program in advance to know what you can't miss, and you have to arrange your evening as a result. And then there is Le Pain Noir on Mondays. Result: every Monday is booked up... It is this, which is the strength of television. People end up living according to its schedules. The news has been delayed by a quarter of an hour: well, you know that restaurants will see their diners arrive a quarter of an hour later."(Foucault, Michel (1994) [1975] 'A quoi rêvent les philosophes?' In Dits et Ecrits vol. II. Paris: Gallimard, p. 705. (http://blogs.greenville.edu/itdept/2011/03/25/thepower-of-media)

Foucault uses Jeremy Bentham's 'Panopticon' as an image of power and surveillance. Thus, it is metaphorically the image of control for a modern society. A panoptic (all-seeing) power keeps subjects under constant surveillance(Leitch, 2001, p.1618).In a modern society, in the play 'Man of the Moment', the media is a power of control. In the final scene of the play (Act II, p.83), while the characters arguing the incident of death of Vic by the pool, the media staff suddenly shows up, as stated in the play; "Ashley Barnes, a TV Floor Manager, steps on to the floor, appearing unexpectedly and as from nowhere" (p.83). It seems that they control the event from the beginning, even when it seems they disappeared. The actors replace with the real ones, Jill or other TV presenter give instructions, and final scene ends in what they lead. There is no evidence that real characters in the play know the media people observe them and interfere suddenly, from a certain time. It seems real characters do not know they have been observed, or the events have been controlled by the media people. While Storey giving modern examples directly related to panopticon such as CCTV cameras, he goes on to explain that perhaps the most obvious examples are television programs such as Big Brother, I'm a Celebrity(2008, p.132). The play 'Man of the Moment' ends in a surrealistic way. However, this approach (finale starting from the appearance of the media staff, actors) is enough to understand the surveillance and power of the media on people.The TV medium starts the events and, by suddenly interfering, ends them; the birth and death of a hero (but as a hero). Foucault argues surveillance has become the dominant mode of the operation of power. 'Panopticism is a form of power . . . organised around the norm, in terms of what [is] normal or not, correct or not, in terms of what one must do or not do' (2002, pp.58-59).

In essence Foucault agreed with the adage that 'knowledge is power' (condensing this principle to 'power/knowledge'), arguing that power is implicated in the manner in which certain knowledge is applied (Hall, 1997, p.48). While defining discourse, Foucault (1989, p.49) explains, discourses are 'practices that systematically form the objects of which they speak'. Storey states that Foucault's concept of discourse is similar to Althusser's idea of the 'problematic'; that is, both are organized and organizing bodies of knowledge, with rules and regulations which govern particular practices (ways of thinking and acting) (2008, p.128). When media's discourse is to produce its truth as a power, as having knowledge, as Storey points out power produces reality; through discourses it produces a truth we live by $(2008$, p.130). This relation proves Foucault (1980) right about the relation between power and knowledge. Media as a power, via Jill, a TV presenter, regulates conditions to do a program of meeting Vic, the bank robber, and Douglas, the bank clerk and the hero of the raid, seventeen years later as an innocent-seemed meeting to public. 
However, in the background Vic is already a celebrity, he has become popular like a hero after prison, and obviously the program will contribute to the reputation of Vic, Jill, and of course to benefit of the media. Accordingly, Wagler (2009, p.332) expresses clearly about Foucault's 'regime of truth' depending upon power/knowledge: "For Foucault power/knowledge are coupled in 'regimes of truth'. In Foucault's world, knowledge is not seen as corresponding to absolute truth, but is rather a product of the rules for determining what can count as true, rules that are often set by those who define what 'truth' is (i.e. those in power). Within this power/ knowledge paradigm, truth as well as knowledge is produced".

Public knows Vic as a celebrity, a folk hero, from TV and his books. Most probably they do not think about Vic's background anymore, they just know him as a famous person on TV, even he was infamous in the very beginning. This is actually because of the media. In the play 'Man of the Moment', we, as readers or the audience, know Jill, a representative of the media, is behind Vic's being a celebrity, a hero, however, in play's reality, in that world, people do not know, even do not care who the writer, in other words, who 'the author' is behind the story. This, metaphorically, matches up with the expressions of Foucault on what he says about an 'author' in his article 'What is an Author?':

"All discourses ... would then develop in the anonymity of a murmur. We would no longer hear the questions that have been rehashed for so long: Who really spoke? Is it really he and not someone else? With what authenticity or originality? And what part of his deepest self did he express in his discourse? Instead there would be other questions, like these: What are the modes of existence of this discourse? Where has it been used, how can it circulate, and who can appropriate it for himself? What are the places in it where there is room for possible subjects? Who can assume these various subject functions? And behind all these questions, we would hear hardly anything but the stirring of indifference: What difference does it make who is speaking?" (Foucault, 1984, pp. 119-120)

In his depiction of what an author is, Foucault, in a sense, predicts about the function of the media indirectly. Moreover, what he says matches up better with the Internet technology and its services as Poster (2010, pp.4-5) states that Foucault seems to anticipate the world of chat rooms, email, blogs, and web pages where authorship is always in question. He seems to depict and even to desire a space of communication where identity may be in doubt and may be subordinated to the flow of text, to the impulses of creativity. And yet the word "media" is absent from the vocabulary of the critic of authorship.

Public follows and learns the events in the media from point of view of the media, and they, if they do not search in a detailed way, know about the events in a way media presents. Baudrillard's (1996) argument that the Gulf War did not take place can be an ironic example to media's approach. Thus Derrida's statement 'nothing beyond the text'(Smart, 2000, p.453) and Foucault's depiction of 'What is an author?' are in a sense more functional when thought in parallel with the media's approach on reflecting things or events. Public sees Vic as a celebrity and a hero as presented by the media, and they do not regard his background and other innocent people, may be they do not need to consider them. Intentionally or not, they expect the 'evil's' story to be flowed rather than the good.

If one considers Foucault's statements of 'discourse' and 'subject' as individuals' producing a text in social life, one can apply it to the mass media in terms of having potential power and using it. Stuart Hall notes of Foucault's implications for understanding representation: "It is discourse, not the subject who speaks it, which produces knowledge. Subjects may produce particular texts, but they are operating within the limits of the episteme, the discursive formation, the regime of truth, of a particular period and culture. Indeed, this is one of Foucault's most radical propositions: the 'subject' is produced within discourse. This subject of discourse cannot be outside discourse, because it must be subjected to discourse. It must submit to its rules and conventions, to its dispositions of power/knowledge".(1997, p.48)

If we think a journalist or a TV presenter as a subject in terms of Foucault's statements, we can explore that the truth presented/given by him/her as a discourse may be used for the sake of power. Jill, working for the media, created a hero, and it does not matter whether the media wanted her to do it, or she did and media allowed it and did not question. There is not an absolute power, but there is a relation of power. Maybe, the question of "who or what has more power?' can be discussed. Accordingly, people care about what is said rather than who said, or presented, it. They do not question who said and why. Continuous reputation of Vic is a proof of people's not questioning his background and personality, and accepting it as it is. 
Besides, Derrida's 'there is nothing beyond the text' and Foucault's 'What is an author?' are crucial when the source of any medium is uncertain, or unimportant in the eye of public. Foucault defines 'technologies of the self' as ethics referring to a person's concern for the self - a set of internal ideas or loose rules. In parallel with the Foucault's definition, Gauntlett (2008, p.126) states that we might as well understand technologies of the self as the (internal and external) practice of our (internal) ethics. The ethics are our set of standards to do with being a particular sort of person; technologies of the self are how we think and act to achieve this. Vic, among the characters of the play, is a dominant character. He disregards others' thoughts if they do not suit his benefit. That is his significant quality revealed in the play, and he has a chance to perform this characteristic to public with the help of the media, not only to people around him. One can claim there is a mutual relation of benefit between Vic and the media.

\section{Conclusion}

Ayckbourn's 'Man of the Moment' is one of the crucial references of modern drama because of dealing with the issues of 'good' and 'evil' in a modern way. He chose classical themes, but he produced a modern approach by putting the media into the center of the play together with good and evil characters. Ayckbourn states that in the play he examines the nature of celebrity and fame via the characters related directly or indirectly to the media. In other words, Ayckbourn's point of view is a moral looking at good and evil from the perspective of media ethics and (false) values. The folk hero of the media, Vic, and the media representative, Jill, have a kind of relation that they use power for mutual benefit. In other words, Vic's dominant and in a way influencing character helps media as a 'material'. Foucault's ideas and theories on power/knowledge, that power is nothing but a relation as a modern approach if compared to traditionalist ones such as Marx's, was applied to the Ayckbourn's play. Consequently, an example of modern drama written in a modern approach was analyzed in terms of power's modern definition in light of, mostly, Foucault's thoughts and theories.

\section{References}

Ayckbourn, Alan. Man of the Moment. Faber \& Faber, 1990.

Baudrillard, J.. The Gulf War Did Not Take Place (Trans. P. Patton). Power Publications, Sydney, 1996

Foucault, Michel, Discipline and Punish, Harmondsworth: Penguin, 1979.

Foucault, Michel, Power-Knowledge: Selected Interviews \& Other Writings, Ed by Colin Gordon, Tr. by C. Gordon et. al., Pantheon Books, New York 1980, pp. 93-96.

Foucault, Michel. The Subject and Power. Critical Inquiry, Vol.8, No.4, pp.777-795, 1982, p.786.

Foucault, Michel. "What is an Author?" Ed. P. Rabinow. The Foucault Reader. New York: Pantheon. 101-120. 1984

Foucault, Michel.The Archaeology of Knowledge, London, Routledge. 1989

Foucault, Michel, 'Truth and juridical forms', in James D. Fabion (ed.), Michel FoucaultEssential Works: Power, Harmondsworth: Penguin, 2002.

Gauntlett, David. Media, Gender and Identity: An Introduction. Routledge, New York, 2002

Hall, S. (Ed.). Representation: Cultural Representations and Signifying Practices. London The Open University/Sage Publications, 1997.

Leitch, Vincent B.. The Norton Anthology of Theory and Criticism. W.W. Norton\&Company, New York, 2001

Murgatroyd, Simon. The Alan Ayckbourn Guides: Man of the Moment. www.alanayckbourn.net, 2009.

Poster, Mark. McLuhan and the Cultural Theory of Media. Media Tropes eJournal, Vol II, No. 2, 2010.

Smart, B. Postmodern Social Theory. In B. S. Turner (Ed.), The Blackwell Companion to Social Theory (2nd ed., pp. 47-480). Oxford: Blackwell. 2000

Storey, John. Cultural Theory and Popular Culture: An Introduction. Fifth edition, Pearson Longman, 2008.

Wagler, Ron. Foucault, the Consumer Culture and Environmental Degradation. Ethics, Place and Environment Vol. 12, No. 3, October 2009, 331-336. Routledge<http://blogs.greenville.edu> 